\title{
Promoting Student Intercultural Communicative Competence in the Japanese Context
}

\section{Adam Christopher \\ Monash University}

\section{Reference Data:}

Christopher, A. (2020). Promoting student intercultural communicative competence in the Japanese context. In P. Clements, A. Krause, \& R. Gentry (Eds.), Teacher efficacy, learner agency. Tokyo: JALT. https://doi.org/10.37546/JALTPCP2019-38

The impact of culture on language has been acknowledged for many years (Vygotsky, 1962) as well as how local culture may influence the communication strategies and interactions of EFL well as how local culture may influence the communication strategies and interactions of EFL
learners. Since intercultural communicative competence is the key to such communication, I investigated the perceptions of Japanese university students of integrating American and British cultural activities with language learning both in and outside of the EFL classroom. Data were collected through a questionnaire administered to 78 university students. The results suggest that students had positive attitudes and an interest in developing further understanding of the target language culture both in and outside of class. Furthermore, they believed that the target language culture should be incorporated in the teaching of foreign languages. Therefore, this study highlights the need for integrating the teaching of culture with language instruction into the curriculum in the Japanese context.

言語に対する文化の影響は、長年にわたって広く認識されている(Vygotsky, 1962)。同様に、地域の文化がEFL学習者のコ

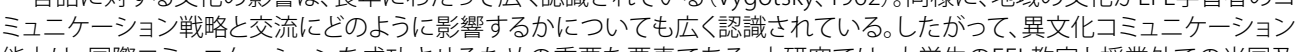
能力は、国祭コミュニケーションを成功させるための重要なな要素である。本研究では大学生のEFL教室と授業外での米国及 び英国の文化活動之語学学習の統合に対する認識走調查している。調査は、日本の大学の78人のEFL大学生に実施された。 結果は、生徒がララスの内外て対象言語の文化を理解することに前向をな姿勢と関心を示したことを示唆している。さらに、 彼らは对象言語の文化が外国語の授業に組み込まれる゙゙きであると信してていたしたがって、この研究は、日本の実情に即し て、文化と言語を統合的に教える必要性を強調している。 n over 12 years of full-time English teaching at the university level in Japan, I have experienced first-hand the challenges that Japanese university students face in becoming interculturally competent English speakers.

Intercultural communicative competence (ICC) refers to the ability to understand cultures, including one's own, and the use of this understanding to successfully communicate with people from other cultures. Knapp and Knapp-Potthoff (1987) stated that intercultural communication (IC) occurs each time a participant draws on different areas of knowledge that are unique to each socio-cultural group during an interaction. In this paper, the abbreviations ICC and IC are used interchangeably to refer to intercultural communicative competence as a skill or ability.

Interactants in intracultural encounters implicitly share the same ground rules of communication and meaning of signals (O'Keeffe, 2004), whereas interactants in intercultural encounters are likely to experience a degree of uncertainty and ambiguity concerning these things (Gudykunst \& Nishida, 2001). In oral exchanges, the meanings of utterances are negotiated jointly by speaker and listener; it is always necessary for the receiver to draw inferences about the intentions of the sender (Scollon \& Scollon, 1995). Thus, it is easy to imagine the potential for misunderstandings and miscommunication in international communication (Cutrone, 2013). Accordingly, knowledge of the conventions, customs, beliefs, and systems of meaning of another culture is indisputably an integral part of foreign language learning.

Despite a relatively long history of English education, learning outcomes in Japan have been remarkably poor, especially in terms of speaking skills. Although Japan has invested enormous resources in English education, Japanese students continue to obtain among the lowest scores among Asian countries on standardized English proficiency tests (Nikolova, 2008) such as the TOEFL (Takahashi, 2005) and TOEIC (ETS, 2009). While the overall failure of English education in Japan has been documented and debated, many analysts have agreed that Japanese learners have the most difficulty acquiring speaking 
skills (Ellis, 1991; Farooq, 2005; Roger, 2008; Takanashi, 2004). For example, Ellis (1991) suggested that Japanese high school and college graduates are incompetent as English speakers, especially in terms of sociolinguistic competence. Farooq (2005) argued that even at a survival level, Japanese EFL learners have extreme difficulties interacting with native speakers in real-world situations. Scores on the newly developed TOEFL iBT, which was designed to include a speaking assessment, have also indicated that Japanese learners have fundamental problems with oral tasks (ETS, 2009). Hidasi (2004) suggested potential factors that could have a negative impact on foreign language acquisition. This included lack of student exposure to real-world ICC and differences in Japanese ways of thinking that plays a major role in communication behavior.

Ellis (1991) explored Japanese learners' failure to acquire sociolinguistic competence in English and how some characteristics that researchers have ascribed to Japanese communication styles may influence their spoken encounters in English. He described the general features of these styles in comparison with those of native English speakers. These included being less verbal and more inclined to use silence and back-channeling devices in intercultural interactions. This suggests that there may be strong cultural influences that affect and sometimes hinder native Japanese English speakers' abilities, and many of these influences are linked to affective variables such as foreign language acquisition, self-confidence, anxiety, and motivation.

Understanding the process by which these different communication styles function and improving learners' attitudes toward intercultural communication may be necessary to improve their overall communicative competence. However, the degree to which subjects such as foreign languages are intercultural depends on curriculum orientation (Davies \& Read, 2005). Foreign language teaching can involve exposing students to a variety of texts and representations of the foreign culture in order to develop their critical understanding of the cultural aspects of the target language and cultural representations (Byram \& Feng, 2004; Ware \& Kramsch, 2005). However, researchers argue that experiential learning about the target culture is more effective than learning that is confined to classrooms (Byram \& Feng, 2004).

Classroom teaching that incorporates experiential elements is often used to enhance both language learning and cultural understanding (Byram \& Feng, 2004), as it widens students' perspectives by allowing comparison of their own and different points of view. The Internet can also be used to explore cultural representations and enable students to develop intercultural awareness, intercultural communicative competence, and language skills (Baker, 2013; Dervin, 2014; Elola \& Oskoz, 2008). Students can acquire cultural competency by using English to understand what seems to be culturally ambiguous to them. Furthermore, Su (2014) argued for the necessity of integrating authentic learning experiences with language education through study abroad programs.

Popular culture is generally recognized by members of a society as a set of practices, beliefs, and objects that are dominant or prevalent in a society at a given point in time and that tend to influence an individual's attitudes towards certain topics (McGaha, 2015). Introducing American and British popular culture in class can generate student curiosity about exploring those cultures. For example, students can acquire information about a pop song as a cultural product with its sociocultural and regional information. This is in line with Engh (2013) and Yarmakeev, Pimenova, Abdrafikova, and Syunina (2016), who argued that pop songs help students become aware of the cultural heritage of different societies and better understand the values of members of the target language culture. Moreover, intercultural lessons can reflect the five principles of intercultural language learning proposed by Liddicoat, Papademetre, Scarino, and Kohler (2003): (1) active construction; (2) making connections; (3) social interaction; (4) reflection; and (5) responsibility. These five principles are further explained below.

\section{(1) Active construction}

Students construct intercultural knowledge through research, discussions with peers, interviews with native speakers of the target language and role-playing and problemsolving of critical incidents.

\section{(2) Making connections}

Students explore themselves, develop an awareness of cultural stereotypes and new insight into the target culture as they make connections with their own culture. By connecting the target culture with their home culture, students are able to develop critical cultural awareness about different aspects of the target culture and their own culture. The process of noticing is emphasized in this principle as it is fundamental to intercultural language learning (Liddicoat et al., 2003). The process of comparison is multilayered in that it allows space for comparisons between the learner's home culture and the target culture as well as between their linguistic and cultural background knowledge and new input from noticing (Liddicoat, 2008).

\section{(3) Social interaction}

Students participate in different types of social interaction such as role-plays and ethnographic interviews. 


\section{(4) Reflection}

Students participate in group discussions and reflect critically on their experience of cultural learning in the classroom. Reflections can develop learners' critical thinking, increase their consciousness of cultural similarities and differences in values, and help them become more aware of the assumptions of English-speaking cultures and their own culturally-shaped assumptions.

\section{(5) Responsibility}

According to Liddicoat et al. (2003), students ideally develop positive attitudes and disposition towards cultural learning. They need to take responsibility for making communication successful and developing an intercultural perspective that values other cultures and people.

Given the importance of ICC demonstrated in the literature, the present study is aimed at investigating the perceptions of Japanese university students of integrating target-culture learning activities in the EFL classroom and outside of class as well as their views on the teaching of the target culture along with language in Japanese EFL classes.

\section{Methodology \\ Context and Participants}

This study was conducted at a Japanese national university located in Tokyo with an enrollment of approximately 4,000 students and a mission of conducting research and instruction on world languages and cultures in 26 departments of languages, including the School of Language and Culture Studies (1,480 students). Three-hundred and seventy 1st-year students from the School of Language and Culture Studies were asked to complete the questionnaire, and a total of 153 returned it before the deadline of data collection. Eighty questionnaires were randomly chosen, and two of those were discarded due to incomplete answers. At the time of this study, all of the students were in their first year and were of high intermediate proficiency, with TOEIC scores between 600 and 900.

\section{Data Collection}

Data were collected through a questionnaire adapted from Kiet (2011) focusing on students' views of language instruction that incorporated information about American and British cultures, the activities they found useful in learning target-language culture both in class and out, their perceptions of the value of these learning activities, their evaluation of the benefits of learning about the target-language culture, and their views on whether the target culture should be taught together with the target language in EFL classes in Japan (see Appendix). The questionnaire consisted of 5-point Likert-scale items in Japanese and was administered in November 2019. The students were asked to specify their level of agreement or disagreement (from least useful to most useful). Descriptive statistics were calculated and were used as part of the results below.

Results

Student Views on Target-Culture Learning in Class

Table 1 shows that showing respect for otherness and having empathy and tolerance towards other people and cultures $(M=3.72)$, acquiring knowledge about the target culture $(M=3.39)$, and developing communicative awareness of rules appropriate for intercultural communication $(M=3.30)$ were the students' top three purposes for target-culture learning.

Table 1. Students' Purposes for Learning About the Target Culture

\begin{tabular}{lcc}
\hline \multicolumn{1}{c}{ ICC components } & M & SD \\
\hline $\begin{array}{l}\text { Showing respect for otherness and having empathy and tolerance } \\
\text { towards other people and cultures }\end{array}$ & 3.72 & 1.16 \\
$\begin{array}{l}\text { Acquiring knowledge about the target culture } \\
\begin{array}{l}\text { Developing communicative awareness of rules appropriate for } \\
\text { intercultural communication }\end{array}\end{array}$ & 3.39 & 1.17 \\
$\begin{array}{l}\text { Developing the ability to interpret events of the target culture and } \\
\text { relate them to one's own culture }\end{array}$ & 3.14 & 1.21 \\
$\begin{array}{l}\text { Developing cultural awareness of one's own and the target culture } \\
\text { Acknowledging the value of the identities of others }\end{array}$ & 3.11 & 0.96 \\
Adapting one's behavior to different requirements and situations & 2.86 & 1.09 \\
\hline
\end{tabular}
Note. $N=78 . M$ and $S D$ are calculated on a 5-point scale (1-5).

Students' views on the usefulness of in-class activities for learning about the target culture are shown in Table 2. Discussing cultural similarities and differences $(M=3.82)$, 
Christopher: Promoting Student Intercultural Communicative Competence in the Japanese Context

sharing experiences about the target culture $(M=3.61)$, watching videos about the target culture $(M=3.47)$, and exploring values and beliefs of the target culture $(M=3.25)$ were the students' highest-rated activities. However, the remaining activities show a narrow spread in mean scores $(M=2.97-2.43)$ and standard deviation range $(S D=1.31-1.18)$. Since discussing cultural similarities and differences was the most useful $(M=3.82)$, and solving cultural dilemmas was rated the lowest $(M=2.43)$, the target-culture learning activities associated with the exploration of cultures were considered the most useful.

Table 2. Students' Views on the Usefulness of Activities for Learning About the Target Culture

\begin{tabular}{lcc}
\hline \multicolumn{1}{c}{ Target Cultural Learning Activities } & M & SD \\
\hline Discussing cultural similarities and differences & 3.82 & 1.12 \\
Sharing experiences about the target culture & 3.61 & 1.07 \\
Watching videos about the target culture & 3.47 & 1.37 \\
Exploring values and beliefs of the target culture & 3.25 & 0.99 \\
Learning cultural facts from reading texts & 2.97 & 1.18 \\
Doing exercises about cultural facts & 2.77 & 1.15 \\
Answering teacher's questions about cultural facts & 2.55 & 1.15 \\
Solving cultural dilemmas & 2.43 & 1.31 \\
\hline
\end{tabular}

Note. $n=78 . M$ and $S D$ are calculated on a 5-point scale (1-5).

Table 3 shows students' responses regarding target-culture learning activities outside of class. The mean scores indicate the degree of usefulness of each activity. The results show that searching for cultural information on the Internet $(M=3.73)$, watching English TV channels $(M=3.44)$, and reading English literature $(M=3.27)$ were the students' top three activities, while searching for cultural information on the Internet was considered the most useful $(M=3.73)$, meeting native English speakers visiting your school was the least useful $(M=2.34)$. Thus, media was perceived by the students as the main source for targetculture learning outside the classroom. It is possible that students considered the media important due to lack of contact with native English speakers.
Table 3. Students' Culture Learning Activities Outside of Class

\begin{tabular}{lcc}
\hline \multicolumn{1}{c}{ Cultural Learning Activities } & M & SD \\
\hline Searching for cultural information on the Internet & 3.73 & 1.08 \\
Watching English TV channels & 3.44 & 1.50 \\
Reading English literature & 3.27 & 1.36 \\
Reading English newspapers/magazines & 2.64 & 1.51 \\
Communicating with native English speakers in public & 2.54 & 1.56 \\
Meeting native English Speakers at your school & 2.34 & 1.58 \\
\hline
\end{tabular}

Note. $N=78 . M$ and $S D$ are calculated on a 5-point scale (1-5).

Table 4 indicates students' perceptions of the value of different aspects of targetculture learning. The results show that students agreed that learning about [the target] culture [helped them] become more tolerant and open-minded toward other peoples and cultures $(M=4.37)$, that learning about [the target] culture is as important as learning about language in an English class $(M=4.12)$, and that they needed to understand [their] own culture first before learning about other cultures $(M=4.07)$. The lowest rated item was misunderstanding in intercultural communication is mostly due to language problems rather than cultural differences $(M=3.13)$. The results suggest that the students had positive perceptions of learning about other cultures as allowing them to be more tolerant and open-minded. They had an awareness that language and learning about other cultures were important, and they also demonstrated an appreciation of their own culture. 
Table 4. Student' Perceptions of the Value of Target-Culture Learning

\begin{tabular}{|c|c|c|c|}
\hline \multicolumn{2}{|r|}{ Perceptions } & $\mathbf{M}$ & SD \\
\hline \multicolumn{2}{|c|}{$\begin{array}{l}\text { Learning about culture helps me become more tolerant and open- } \\
\text { minded towards other peoples and cultures. }\end{array}$} & 4.37 & 0.82 \\
\hline \multicolumn{2}{|c|}{$\begin{array}{l}\text { Learning about culture is as important as learning about language in } \\
\text { an English class. }\end{array}$} & 4.12 & 0.83 \\
\hline \multicolumn{2}{|c|}{$\begin{array}{l}\text { I need to understand my own culture first before learning about other } \\
\text { cultures. }\end{array}$} & 4.07 & 0.93 \\
\hline \multicolumn{2}{|c|}{$\begin{array}{l}\text { I need to learn about the language first before learning about the target } \\
\text { culture. }\end{array}$} & 3.71 & 1.08 \\
\hline \multicolumn{2}{|c|}{$\begin{array}{l}\text { My own culturally shaped knowledge does not influence much the way } \\
\text { I interact with people from other cultures. }\end{array}$} & 3.71 & 1.14 \\
\hline \multicolumn{2}{|c|}{$\begin{array}{l}\text { I can acquire both additional cultural knowledge and intercultural } \\
\text { skills in the classroom. }\end{array}$} & 3.32 & 0.90 \\
\hline \multicolumn{2}{|c|}{$\begin{array}{l}\text { Misunderstanding in intercultural communication is mostly due to } \\
\text { language problems rather than cultural differences. }\end{array}$} & 3.13 & 1.04 \\
\hline \multicolumn{4}{|c|}{$\begin{array}{l}\text { Note. } n=78 . M \text { and } S D \text { are calculated on a } 5 \text {-point scale }(1-5) \text {. The mean scores of these sentences } \\
\text { are calculated in a reverse manner in order to be comparable with other mean scores. }\end{array}$} \\
\hline \multicolumn{4}{|c|}{$\begin{array}{l}\text { Table } 5 \text { summarizes students' perceptions of the benefits of target-culture learning }(M \\
=2.37, S D=.62) \text {. The results, with a high mean score of } 2.37 \text { and low standard deviation, } \\
\text { indicate that students' views were quite consistent. This suggests that the students } \\
\text { agreed that target-culture learning was beneficial to language learning. }\end{array}$} \\
\hline \multicolumn{4}{|c|}{ Table 5. Students' Views on the Benefit of Target-Culture Learning } \\
\hline Very beneficial & To a certain degree & & D \\
\hline 35 & 2.37 & & 62 \\
\hline
\end{tabular}

Note. $n=78 . M$ and $S D$ are calculated on a three-point scale (1-3).

Table 6 indicates students' overall views on the teaching of language and target-culture learning $(M=2.49, S D=.66)$. The results show a high mean score $(M=2.49)$ and a low standard deviation $(S D=.66)$, which indicates that students' views were fairly consistent. Furthermore, the results show that most students agreed that the target culture should be taught together with the target language in their EFL classes. In addition, 27 students were in favor of integrating target culture learning in language classes with limitations on teaching time or content.

Table 6. Student' Views on Whether the Target Culture Should Be Taught

\begin{tabular}{ccccc}
\hline Yes & With limitation & No & M & SD \\
\hline 45 & 27 & 6 & 2.49 & 0.66 \\
\hline
\end{tabular}

Note. $n=78 . M$ and $S D$ are calculated on a three-point scale (1-3).

\section{Discussion}

Overall, the students had positive perceptions of learning about the target culture since they believed that it helped them to become more tolerant, open-minded, and appreciative of their own culture. The results also suggest that students were generally in favor of integrating language learning with target-culture learning. Moreover, they saw the purpose of cultural learning as involving the ICC dimensions of respect for others and empathy and tolerance towards other peoples and cultures. These findings agree with those of Byram, Gribkova, and Starkey (2002), who state that incorporating ICC dimensions in language teaching can help learners develop as speakers and mediators who are capable of engaging with the complexities of communication in intercultural environments. This is because this kind of communication requires as a basis for social interaction respect for individuals and the equality of human rights and the avoidance of judging others based on stereotypes (Byram, Gribkova, \& Starkey, 2002).

The results also indicate that for these students the media was the most important means of learning the target language and culture. This finding is in line with GodwinJones's (2013) argument that while traditional textbooks help students to acquire language skills, media can provide students with further language and target-culture learning support, especially through the use of information and communication technologies. Many teachers have realized that fact and encouraged students to communicate with native speakers online. As a result, researchers argue for integrating and using information and communication technologies for language and target-culture learning and development (Baker, 2013; Dervin, 2014; Elola \& Oskoz, 2008; Freiermuth 
\& Huang, 2012; Hamilton \& Woodward-Kron, 2010; Ho, 2000; Pandey \& Ardichvili, 2015; Son \& Park, 2012). Ali and Walker (2014) also assert that TESOL materials should incorporate the target culture. Such materials can be explored through social media, the arts, and English-language films, television, radio, newspapers, novels, and magazines (Baker, 2011).

\section{Implications}

The findings of this study suggest that it is a worthwhile goal to incorporate culture in EFL classes at the university level, where EFL teachers can provide students with meaningful and authentic intercultural experiences that integrate language and content as suggested above. Language courses and programs may include a significant reflective component in order to foster student awareness and intercultural development (Deardorff, 2008). For example, learners can be encouraged to keep a regular journal of target-culture learning. Reflective journals could even be developed into a component of a target-culture portfolio and used as a compulsory assessment to assist their acquisition of intercultural competence. The teacher can also present contemporary global issues that relate to cultural diversity and identity. Students can take turns discussing topics in terms of their cultural principles and norms both inside and outside the classroom. In addition, using authentic materials is an effective means of motivating students to improve their intercultural competency skills. This coincides with Byram's model of ICC (1997), in which foreign language teachers guide students through the process of acquiring attitudes, knowledge, and related skills. When language skills and ICC are linked in a language classroom, students become equipped for participation in global communication and interaction. Furthermore, Anderson (1993) claims that students' perceptions of language and the learning process are culturally derived and may differ drastically from those of their foreign language teachers. Therefore, teachers should create an environment in which target-culture learning is encouraged through the use of communicative activities. This approach also coincides with that of Wright (1996), who argues for raising awareness of the importance of target-culture learning in language education. Although it is often thought that target culture and language can be taught separately, they have been found to be inseparable (Byram, 1997; Kramsch, 1993).

Since modern EFL teaching and learning are aimed at helping language learners' function effectively in English in a globalized world, curriculum designers may need to adopt more interculturally informed platforms. Liddicoat (2008) argues that a classroom is a cultural context where teachers' and learners' verbal and cultural backgrounds shape experiences and expectations. Although discussing culturally sensitive issues may lead to heated arguments (Baldonado, Holm, \& Balquiedra,1997), students can gain global perspectives and learn about cultural differences (Henderson, 2004). The classroom should be treated as a community for students to develop intercultural communicative competence both as preparation for experience and as an experience in itself (Göbel \& Helmke, 2010).

When students and teachers see themselves as members of a community and are aware of their own cultural backgrounds, they can extend that awareness to interactions with people from other cultures using information and communication technology (ICT) to facilitate ICC. Corbett (2010) argues that learners need to observe, describe, and discuss local linguistic and cultural practices in everyday settings in their own culture first and then share their insights online with online partners. Corbett suggests pairing up learners with people in another country (similar to pen friends) to learn about different cultures through online resources.

\section{Limitations and Directions for Future Research}

This study is limited in that the responses reflect the opinions of self-selected students within a university program with a strong focus on intercultural communication. As a result, their responses may have been biased in favor of the type of activities described here than non-English majors in mandatory English classes. Thus, the results of this study need to be confirmed with students in other settings such as mandatory English classes for non-majors. It would also be useful to conduct in-depth interviews with students to gain more insight into their perceptions. In addition, future research may investigate how students use the target language to develop their intercultural competence, and whether use of the target language affects the connection between linguistic and intercultural competence. As language and culture should be integrated from the beginning of language learning, it is also worth investigating how to introduce an intercultural stance in beginning language courses. This would contribute to enhancing learners' awareness of language and culture from the earliest stages of language learning in order to provide a foundation for them to engage more effectively in target-culture learning at later stages. In order to compensate for the lack of interaction with native target-language speakers in Japanese EFL classes, research can also be conducted on students' participation in online exchanges with people from other cultural backgrounds. This research would contribute to the development of more effective use of online resources. Furthermore, longitudinal research is needed to provide a deeper understanding of how language learners' intercultural communicative competence evolves over longer periods. For example, researchers could investigate 
how students develop their intercultural communicative competence over extended periods of time, which might help teachers determine suitable levels of intercultural communicative competence that students can be expected to acquire at different levels of language proficiency.

\section{Conclusion}

The Japanese students' perceptions of target culture learning seemed to reflect a genuine interest in and positive experience with target-culture learning, both in and out of the EFL class. Students agreed that the target culture should be introduced along with the target language in their EFL classes in order to develop their ICC skills through activities inside and outside class. The study highlights the need to integrate language and target culture into language learning, rather than having a separate course on intercultural language learning. A number of factors need to be considered, such as lesson goals, intercultural knowledge input, teacher roles, student roles, classroom settings, and intercultural activities. Intercultural activities can be built on the five principles of intercultural language learning proposed by Liddicoat et al. (2003). Teachers' IC experiences can change the learning outcomes of their students, so it is important that native Japanese English teachers have more opportunities to engage in IC exchanges overseas.

\section{Bio Data}

Adam Christopher is working towards his Doctor of Philosophy (Ph.D.) in applied linguistics at Monash University, School of Languages, Literatures, Cultures and Linguistics. His research interests include learner autonomy, applied linguistics, intercultural communication, curriculum development, comparative culture, CALL, and EAP. <tamago700@yahoo.com>

\section{References}

Ali, M. M., \& Walker, L. A. (2014). From home culture to intercultural knowledge base: Implications for TESOL materials design. The Asian EFL Journal Professional Teaching Articles, 78, 27-36. Retrieved from: https://www.researchgate.net/publication/331731836_From_home culture_to_intercultural_knowledge_base_Implications_for_TESOL_materials_design

Anderson, F. E. (1993). The enigma of the college classroom: Nails that don't stick up. In P. Wadden (Ed.). A handbook for teaching English at Japanese colleges and universities (pp. 101-110). Oxford: Oxford University Press.
Baker, W. (2011). From cultural awareness to intercultural awareness: Culture in ELT. ELT Journal, 66, 62-70. https://doi.org/10.1093/elt/ccr017

Baker, W. (2013). Using e-learning to develop intercultural awareness in ELT: A critical evaluation in a Thai higher education setting. London: British Council ELT research papers. Retrieved from: https://www.teachingenglish.org.uk/sites/teacheng/files/B375\%20ELTRP\%20report\%20-\%20 Baker\%20A4\%20ONLINE_V5.pdf

Baldonado, A., Holm, K., \& Balquiedra, N. (1997). Cultural/ethnicity issues in the classroom. Hoitotiede, 9(5), 231-236

Byram, M. (1997). Teaching and assessing intercultural communicative competence. Clevedon, UK: Multilingual Matters.

Byram, M., \& Feng, A. (2004). Culture and language learning: Teaching, research and scholarship. Language Teaching, 37(3), 149-68. https://doi.org/10.1017/S0261444804002289

Byram, M., Gribkova, B., \& Starkey, H. (2002). Developing the intercultural dimension in language teaching: A practical introduction for teachers. Strasbourg, France: Council of Europe.

Corbett, J. (2010). Intercultural language activities. Cambridge, UK: Cambridge University Press.

Cutrone, P. (2013). Assessing pragmatic competence in the Japanese EFL context: Towards the learning of listener responses. Newcastle, UK: Cambridge Scholars Publishing.

Davies, L., \& Read, A. (2005). Globalising citizenship education? A critique of 'global education' and 'citizenship education'. British Journal of Educational Studies, 53(1), 66-89. https://doi. org/10.1111/j.1467-8527.2005.00284.x

Deardorff, D. K. (2008). Intercultural competence: A definition, model and implications for education abroad. In V. Savicki (Ed.), Developing intercultural competence and transformation (pp. 32-52). Sterling, VA: Stylus Publishing, LLC.

Dervin, F. (2014). Exploring 'new' interculturality online. Language and Intercultural Communication, 14(2), 191-206. https://doi.org/10.1080/14708477.2014.896923

Ellis, R. (1991). Communicative competence and the Japanese learner. JALT Journal, 13(2), 103-127.

Elola, I., \& Oskoz, A. (2008). Blogging: Fostering intercultural communication competence development in foreign language and study abroad contexts. Foreign Language Annals, 41(3), 454477. https://doi.org/10.1111/j.1944-9720.2008.tb03307.x

Engh, D. (2013). Why use music in English language learning? A survey of the literature. English Language Teaching, 6(2), 113-127. https://doi.org/10.5539/elt.v6n2p113

ETS. (2009). TOEFL test and score data summary for internet-based and paper-based tests: JanuaryDecember 2007 test data. Retrieved from https://www.ets.org/Media/Research/pdf/71943_web. pdf\#search=\%27TOEFL+test+and+score+data+summary+for+internetbased+and+paperbased+te sts\%3A+JanuaryDecember+2007+test+data\%27 
Farooq, M. U. (2005). A model for motivating Japanese EFL learners through real-life questioning strategies. The Journal of Nagoya Gakkugei University, 1(1), 27-42.

Freiermuth, M. R., \& Huang, H. C. (2012). Bringing Japan and Taiwan closer electronically: A look at an intercultural online synchronic chat task and its effect on motivation. Language Teaching Research, 16(1), 61-88. Retrieved from https://www.learntechlib.org/p/110411/. https://doi. org/10.1177/1362168811423341

Göbel, K., \& Helmke, A. (2010). Intercultural learning in English as foreign language instruction: The importance of teachers' intercultural experience and the usefulness of precise instructional directives. Teaching and Teacher Education, 26, 1571-1582. https://doi.org/10.1016/j. tate.2010.05.008

Godwin-Jones, R. (2013). Integrating intercultural communication competence into language learning through technology. Language Learning \& Technology, 17(2), 1-11.

Gudykunst, W., \& Nishida, T. (2001). Anxiety, uncertainty, and perceived effectiveness of communication across relationships and cultures. International Journal of Intercultural Relations, 25(1), 55-71. https://doi.org/10.1016/S0147-1767(00)00042-0

Hamilton, J., \& Woodward-Kron, R. (2010). Developing cultural awareness and intercultural communication through multimedia: A case study from medicine and the health sciences. System, 38, 560-568. https://doi.org/10.1016/j.system.2010.09.015

Henderson, S. (2004). Strengthening cultural awareness in the classroom: A case in point. In Seeking Educational Excellence: Proceedings of the 13th Annual Teaching Learning Forum, Perth: Murdoch University. Retrieved from http://clt.curtin.edu.au/events/conferences/tlf/tlf2004/ henderson.html

Hidasi, J. (2004, April). The impact of culture on second language acquisition. Paper presented at the Comparative Pragmatics Association 2nd Conference, Tokyo. Retrieved from: http://www.childresearch.net/RESOURCE/RESEARCH/2006/exfile/HIDASI.pdf

Ho, C. M. L. (2000). Developing intercultural awareness and writing skills through email exchange. The Internet TESL Journal,6(12). Retrieved from http://iteslj.org/Articles/Ho-Email.html

Kiet, H. S. T. (2011). An intercultural perspective on teaching and learning in the Vietnamese EFL classroom. University of Sydney Papers in TESOL, 6(3), 43-69.

Knapp, K., \& Knapp-Potthoff, A. (1987). Instead of an introduction: Conceptual issues in analyzing intercultural communication. In K. Knapp, E. Werner, \& A. Knapp-Potthoff (Eds.), Intercultural communication: Studies in anthropological linguistics 1 (pp. 1-13). Berlin, Germany: Mouton de Gruyter. https://doi.org/10.1515/9783110874280

Kramsch, C. (1993). Context and culture in language teaching. Oxford: Oxford University Press.

Liddicoat, A. J. (2008). Pedagogical practice for integrating the intercultural in language teaching and learning. Japanese Studies, 28(3), 277-290. https://doi.org/10.1080/10371390802446844
Liddicoat, A. J., Papademetre, L., Scarino, A., and Kohler, M. (2003). Report on intercultural language learning. Canberra: Commonwealth of Australia.

McGaha, J. (2015). Popular culture and globalization. Multicultural Education, 23(1), 32-37.

Nikolova, D. (2008). English teaching in elementary schools in Japan: A review of a current government survey. Asian EFL Journal, 10(1). Retrieved from: https://asian-efl-journal.com/ March_2008_EBook.pdf

O'Keeffe, A. (2004). 'Like the wise virgins and all that jazz': Using a corpus to examine vague categorisation and shared knowledge. Language and Computers, 52(1), 1-20. https://doi.org/10.1163/9789004333772_002

Pandey, S., \& Ardichvili, A. (2015). Using films in teaching intercultural concepts: An action research project at two universities in India and the United States. New Horizons in Adult Education \& Human Resource Development, 27(4), 36-50. https://doi.org/10.1002/nha3.20121

Roger, A. (2008). Teaching the speaking skill to Japanese students part 1: Construct \& practice. The Journal of Kanda University of International Studies, 20(1), 1-26.

Scollon, R., \& Scollon, S. (1995). Intercultural communication: A discourse approach. Oxford: Blackwell.

Son, J. B., \& Park, J. Y. (2012). Intercultural usability of language learning websites. International Journal of Pedagogies and Learning, 7(2), 135-141. https://doi.org/10.5172/ijpl.2012.7.2.135

$\mathrm{Su}$, Y. C. (2014). The international status of English for intercultural understanding in Taiwan's high school EFL textbooks. Asia Pacific Journal of Education, 36(3), 390-408. https://doi.org/10.1080/02188791.2014.959469

Vygotsky, L. (1962). Thought and language. Cambridge, MA: MIT Press. https://doi.org/10.1037/11193-000

Takanashi, Y. (2004). TEFL and communication styles in Japanese culture. Language, Culture and Curriculum, 17(1), 1-14. https://doi.org/10.1080/07908310408666678

Takahashi, M. (2005). The efficacy of grammar instruction in EFL classes in Japan (Unpublished PhD thesis). Kobe Shoin Graduate School of Letters, Kobe, Japan. Retrieved from http://ksw.shoin. ac.jp/lib/thesis/takahashi/takahashi2005.pdf\#search=\%27Takahashi+\%2C+M.+\%282005\%29.+T he+efficacy+of+grammar+instruction+in+EFL+classes+in+Japan.+Unpublished $+\mathrm{PhD}+\mathrm{Thesis} \% 2 \mathrm{C}$ + Kobe+Shoin+Graduate+School+of+Letters\%2C+Kobe\%27.

Ware, P. D., \& Kramsch, C. (2005). Toward an intercultural stance: Teaching German and

English through telecollaboration. The Modern Language Journal, 89(2), 190-205. https://doi.org/10.1111/j.1540-4781.2005.00274.x

Wright, M. (1996). The cultural aims of modern language teaching: Why are they not being met? Language Learning Journal, 13, 36-37. https://doi.org/10.1080/09571739685200111 
Yarmakeev, l. E., Pimenova, T. S., Abdrafikova, A. R., \& Syunina, A. S. (2016). Folk songs do magic in teaching speech and grammar patterns in EFL class. Journal of Language and Literature, $7(1)$ $235-240$.

\section{Appendix}

\section{Questionnaire}

The Purpose for Cultural Learning

\begin{tabular}{|c|c|c|c|c|c|}
\hline $\begin{array}{l}\text { How important are the following purposes } \\
\text { for your culture learning? }\end{array}$ & 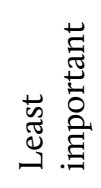 & 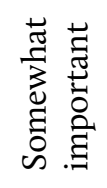 & 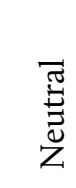 & 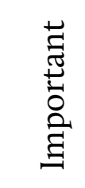 & 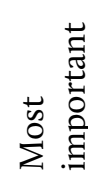 \\
\hline $\begin{array}{l}\text { 1. Acquiring knowledge about the target } \\
\text { culture }\end{array}$ & (1) & (2) & (3) & (4) & (5) \\
\hline $\begin{array}{l}\text { 2. Developing the ability to interpret events } \\
\text { of the target culture and relate them to one's } \\
\text { own culture }\end{array}$ & (1) & (2) & (3) & (4) & (5) \\
\hline $\begin{array}{l}\text { 3. Developing cultural awareness of one's } \\
\text { own and the target culture }\end{array}$ & (1) & (2) & (3) & (4) & (5) \\
\hline $\begin{array}{l}\text { 4. Acknowledging the value of the identities } \\
\text { of others }\end{array}$ & (1) & (2) & (3) & (4) & (5) \\
\hline $\begin{array}{l}\text { 5. Showing respect for otherness, empathy } \\
\text { and tolerance towards other peoples and } \\
\text { cultures }\end{array}$ & (1) & (2) & (3) & (4) & (5) \\
\hline $\begin{array}{l}\text { 6. Developing communicative awareness } \\
\text { of rules appropriate for intercultural } \\
\text { communication }\end{array}$ & (1) & (2) & (3) & (4) & (5) \\
\hline $\begin{array}{l}\text { 7. Adapting one's behavior to different } \\
\text { requirements and situations }\end{array}$ & (1) & (2) & (3) & (4) & (5) \\
\hline
\end{tabular}

\section{Experience of Culture Learning in the EFL Classroom}

\begin{tabular}{|c|c|c|c|c|c|}
\hline $\begin{array}{l}\text { What is your experience of culture learning } \\
\text { in the classroom? }\end{array}$ & 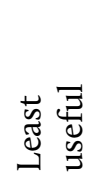 & 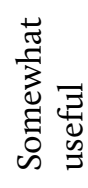 & $\underset{\vec{Z}}{\stackrel{7}{\vec{Z}}}$ & $\begin{array}{l}\overrightarrow{\mathcal{E}} \\
\stackrel{\infty}{D}\end{array}$ & 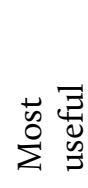 \\
\hline 8. Watching videos about the target culture & (1) & $(2)$ & (3) & $(4)$ & (5) \\
\hline 9. Learning cultural facts from reading texts & (1) & (2) & (3) & $(4)$ & $(5)$ \\
\hline $\begin{array}{l}\text { 10. Answering teacher's questions about } \\
\text { cultural facts }\end{array}$ & (1) & $(2)$ & (3) & $(4)$ & $(5)$ \\
\hline 11. Doing exercises about cultural facts & (1) & (2) & (3) & $(4)$ & $(5)$ \\
\hline $\begin{array}{l}\text { 12. Discussing cultural similarities and } \\
\text { differences between your culture and the } \\
\text { target culture }\end{array}$ & (1) & $(2)$ & (3) & $(4)$ & (5) \\
\hline $\begin{array}{l}\text { 13. Exploring values and beliefs of the target } \\
\text { culture }\end{array}$ & (1) & $(2)$ & (3) & $(4)$ & $(5)$ \\
\hline 14. Solving cultural dilemmas & $(1)$ & $(2)$ & (3) & $(4)$ & (5) \\
\hline $\begin{array}{l}\text { 15. Sharing experience about the target } \\
\text { culture }\end{array}$ & (1) & $(2)$ & (3) & $(4)$ & $(5)$ \\
\hline
\end{tabular}


Experience of Culture Learning Outside the Classroom

\begin{tabular}{|c|c|c|c|c|c|}
\hline $\begin{array}{l}\text { What is your experience of culture learning } \\
\text { outside the classroom? }\end{array}$ & 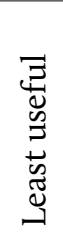 & 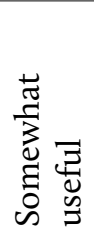 & $\begin{array}{l}\overline{\widetilde{J}} \\
\bar{\Xi} \\
z\end{array}$ & $\begin{array}{l}\vec{Z} \\
\tilde{W} \\
:\end{array}$ & 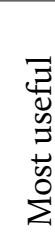 \\
\hline 16. Watching English TV channels & (1) & (2) & (3) & (4) & $(5)$ \\
\hline 17. Reading English newspapers/magazines & (1) & (2) & (3) & $(4)$ & $(5)$ \\
\hline 18. Reading English literature & (1) & (2) & (3) & $(4)$ & $(5)$ \\
\hline $\begin{array}{l}\text { 19. Searching for cultural information on the } \\
\text { Internet }\end{array}$ & (1) & (2) & (3) & (4) & (5) \\
\hline 20. Exchanging emails with NES & (1) & (2) & (3) & (4) & $(5)$ \\
\hline 21. Meeting NES visiting your school & (1) & (2) & (3) & $(4)$ & $(5)$ \\
\hline $\begin{array}{l}\text { 22. Participating in cultural exchange } \\
\text { activities with NES }\end{array}$ & (1) & (2) & (3) & (4) & (5) \\
\hline
\end{tabular}

\section{Student Perceptions on the Value of Culture Learning in Class}

\begin{tabular}{|c|c|c|c|c|c|}
\hline $\begin{array}{l}\text { What are your perceptions of the value of } \\
\text { aspects of culture learning in your English } \\
\text { class? }\end{array}$ & 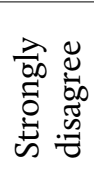 & 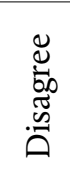 & $\begin{array}{l}\overline{\widetilde{\pi}} \\
\stackrel{\Xi}{\tilde{Z}}\end{array}$ & $\underset{\mathscr{U}}{\rightleftarrows}$ & 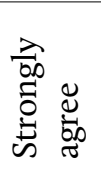 \\
\hline $\begin{array}{l}\text { 23. Learning about culture is as important as } \\
\text { learning about language in an English class. }\end{array}$ & (1) & (2) & (3) & (4) & (5) \\
\hline $\begin{array}{l}24 \text {. I need to learn about the language first } \\
\text { before learning about the target culture. }\end{array}$ & (1) & (2) & (3) & (4) & (5) \\
\hline $\begin{array}{l}25 . \text { I need to understand my own culture first } \\
\text { before learning about other cultures. }\end{array}$ & (1) & (2) & (3) & (4) & (5) \\
\hline $\begin{array}{l}\text { 26. My own culturally-shaped knowledge } \\
\text { does not influence much the way I interact } \\
\text { with people from other cultural backgrounds. }\end{array}$ & (1) & (2) & (3) & (4) & (5) \\
\hline $\begin{array}{l}\text { 27. Learning about culture helps me become } \\
\text { more tolerant and open-minded towards } \\
\text { other peoples and cultures. }\end{array}$ & (1) & (2) & (3) & (4) & (5) \\
\hline $\begin{array}{l}\text { 28. I need to abandon my own cultural } \\
\text { identity while acquiring English. }\end{array}$ & (1) & (2) & (3) & (4) & (5) \\
\hline $\begin{array}{l}29 . \text { I can acquire both additional cultural } \\
\text { knowledge and intercultural skills in the } \\
\text { classroom. }\end{array}$ & (1) & (2) & (3) & (4) & (5) \\
\hline $\begin{array}{l}\text { 30. Misunderstanding in intercultural } \\
\text { communication is mostly due to language } \\
\text { problems rather than cultural differences. }\end{array}$ & (1) & (2) & (3) & (4) & (5) \\
\hline
\end{tabular}


31. To what extent does culture learning help you with your EFL learning? Please circle ONE option and give reasons.

\section{Yes / With limitations / No}

Your reasons:

32. To what extent do you agree with the statement: "The target culture should be taught together with the target language in EFL classes in Japan?" Please Circle ONE option and give reasons.

\section{Yes / With limitations / No}

Your reasons:

(Adopted and adapted from HST. Kiet, 2011) 